\title{
Okun's law in an emerging country: An empirical analysis in Indonesia
}

\author{
Cheng-Wen Lee, Andrian Dolfriandra Huruta
}

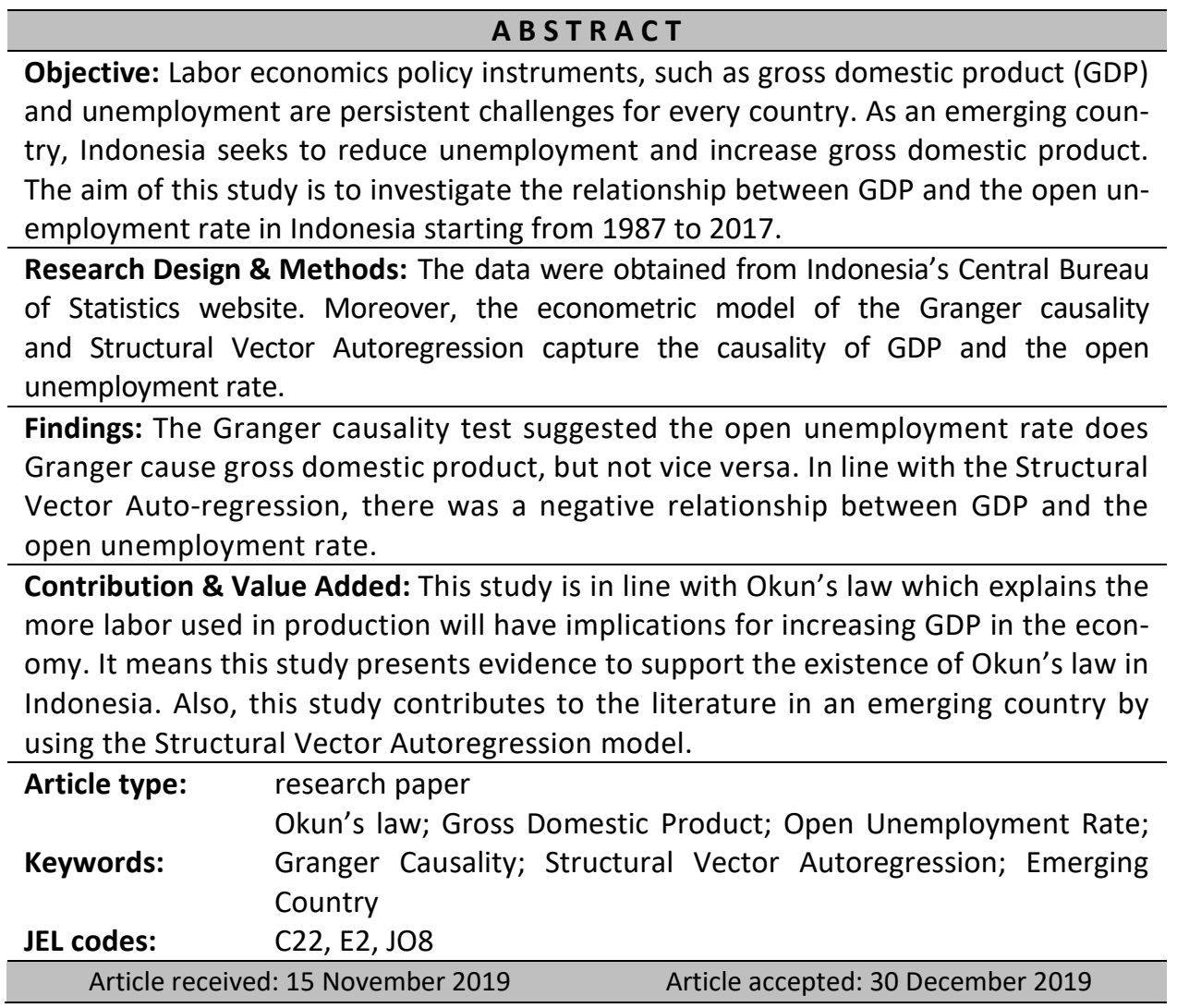

\section{Suggested citation:}

Lee, C.-W., \& Huruta, A.D. (2019). Okun's law in an emerging country: An empirical analysis in Indonesia. International Entrepreneurship Review (previously published as International Entrepreneurship / Przedsiębiorczość Międzynarodowa), 5(4), 141-161. https://doi.org/10.15678/IER.2019.0504.09 


\section{INTRODUCTION}

Economic growth and employment are the two important macroeconomic variables (Bande \& Martın-RoMan, 2017; Blázquez-Fernández, Cantarero-Prieto, \& Pascual-Sáez, 2018; Rahman \& Mustafa, 2017; Soylu, Çakmak, \& Okur, 2018; Pawęta, 2018). Therefore, successful development will be seen from the maintenance of economic growth and job availability for society. The study conducted by Arthur Okun found economic growth had a negative relationship with unemployment. It indicates the higher unemployment rate will reduce economic growth, and vice versa (Okun, 1962).

As an emerging country, Indonesia has discovered and enjoyed high economic growth. During a global financial crisis from 2008 to 2009, the real gross domestic product (GDP) grew positively by $6.0 \%$ in 2008 and $4.5 \%$ in 2009 . From an economic perspective, higher growth contributes to creating employment and reducing unemployment and poverty levels, then causing an increase in welfare. However, the unemployment rate remained high after the financial crisis in 1999. In 2007, the unemployment rate was $9.11 \%$ of the total workforce, which was higher than the one before the crisis in 1997 (4.7\%) (Central Bureau of Statistics, 2019a).

In terms of employment, Indonesia still faces the low minimum wage and high unemployment rate (Yaumidin, 2009). This indicates the growth of new job seekers is faster than the creation of employment opportunities. Before the 1997 crisis, Indonesia had the lowest unemployment rate during the 1980s. In Indonesia, the economic growth is not always followed by a decline in the unemployment rate from year to year. During the period of 1990 to 2006, the relative unemployment rate increased every year, except in 1995, 1997 and 2000, which was down to $0.12 \%, 0.16 \%$, and $0.28 \%$ respectively. Moreover, from 2011 to 2017, unemployment had decreased significantly. However, the decline in the unemployment rate is not always accompanied by an increase in economic growth. Job creation, as a result of economic growth, should absorb the workforce, reduce the number of unemployed people and the unemployment rate (Sasongko, Huruta, \& Pirzada, 2019; Sasongko, Huruta, \& Gultom, 2019; Appiah, Li, Frowne, \& Donkor, 2019). Moreover, the Okun's Law can be used to see the relationship between the economic growth and unemployment more deeply which was by looking at the impact on sub-populations and the economic sub-sector (Bod'a \& Považanová, 2015; Dimian, Aceleanu, lleanu, \& Șerban, 2018; Dixon et al., 2016; Melguizo, 2016; Zanin, 2014, 2016). Thus, it can be understood previous researches still show various results of the relationship between unemployment and output.

This article has identified the existence of Okun's Law in an emerging country particularly Indonesia. We use the time-series analysis such as stationary test, lag length test, Granger causality, Vector Autoregression, White Noise Residual, VAR Stability, Cointegration test, and Structural VAR. The observation period starts from 1987-2017, which includes Indonesia's financial crisis in 1998 and the global financial crisis in 2007-2008.

In addition, this article is arranged in several sections. In the second section, we provide a literature review. In the third section, we provide materials and methods. In the fourth section, we provide findings. The fifth section, we provide discussion, and the sixth section we provide conclusions include limitation and suggestion for future research. 


\section{LITERATURE REVIEW}

Okun's law explains the negative relationship between the unemployment gap $\left(U-U^{n}\right)$ and the output gap $\left(\mathrm{Y}-\mathrm{Y}^{\mathrm{P}}\right)$. It can be understood when the output is above potential, affect the output gap to be positive. While the unemployment rate will be below the natural rate of unemployment. Thus, the unemployment gap becomes negative. Theoretically, a tight negative relationship exists between the unemployment gap and output gap which can be explained in Equation 1.

$$
\mathrm{U}-\mathrm{U}^{n}=-0.5 \mathrm{x}\left(\mathrm{Y}-\mathrm{Y}^{n}\right)
$$

The plot of the unemployment gap and output gap shows a linear relationship. It can be proved by the solid line with a slope of -0.5. Okun's law describes that for each percentage point where the output is above potential, the unemployment rate is one-half of a percentage point below the natural rate of unemployment. Moreover, Okun's law could also be explained that a one percentage point increase in output will lead to a one-half percentage point decrease in unemployment. It reveals that when the output rises, the firms do not increase employment commensurately with the increase in output (e.g., labor hoarding). In fact, the firms were still required their employees to work harder (e.g., increasing their office-hours) (Mishkin, 2016).

There have been many studies on the causality between unemployment and economic growth. In Arab countries, Abdul-Khaliq et al. (2014) who used the Pooled EGLS stated economic growth had a negative and significant effect on the unemployment rate. The nine Arab countries included Algeria, Egypt, Jordan, Lebanon, Morocco, Palestine, Sudan, Syria, and Tunisia. Lebanon had the lowest unemployment rate, while Palestine, Sudan, Tunisia, and Jordan had generally the highest unemployment rate among these countries. In other countries, some increases could be seen in various periods. In Nigeria, Adeyeye et al. (2017) who used the Toda-Yamamoto Granger non-causality and Generalized Method of Moments found there was no causality between unemployment and economic growth. It can be understood that Okun's argument of bidirectional causality between unemployment and economic growth is invalid for Nigeria. Thus, promoting economic growth was such a policy tool for reducing the unemployment rate in Nigeria.

In Jordan, Alamro and Al-dala'ien (2016) who used Autoregressive Distributed Lag and Error Correction Model stated that economic growth had a weak negative short and longrun effect on unemployment. Furthermore, there was a slow response of the labor market to economic development, especially in gaining new skills and suitable training and also the emigrants' labor to Jordan, which made the impact of economic growth to be unsteady in terms of unemployment among the Jordanians. In Greece, a study by Apergis and Rezitis (2003) who used Hodrick-Prescott filter decomposition and the band-pass decomposition proved the Okun's coefficients did not exhibit substantial interregional differences, except for the cases of Epirus and North Aegean Islands. Thus, policymakers must place more emphasis on deregulating certain sectors in the economy, particularly, the labor market. In Nigeria, Arewa and Nwakanma (2012) who used the Vector Autoregressive proved the Okun's coefficient was not significant in the Nigerian economy. However, the trade-off between the output and unemployment-gap was shown to be positive. Therefore, the Nigerian government should provide enabling grounds for a productive minority to operate freely through subsidies, flexible credit facilities, stable, and sustainable electricity. In 
Spain, Azorín and de la Vega (2017) used the spatial Seemingly Unrelated Regressions model stated when the spatial effects were not incorporated, a growth threshold was obtained and could be considered to be notably overvalued. The Okun coefficients varied over time and showed clearly differentiated responses by the employment and unemployment to changes in the output. In Spain, Bande and Martın-RoMan (2017) used Ordinary Least Squares and the Generalized Method of Moments found all of the Okun's coefficients were significant and showed the expected negative sign. All of the Spanish regions portrayed the cyclical behavior of the local labor markets to a greater or lesser extent. In Nigeria, Bankole and Fatai (2013) used Engle-Granger Cointegration and Fully Modified OLS stated that there was a positive coefficient in the regression. It means the Okun's law interpretation was not applicable to Nigeria. It was recommended that the government and policymakers should employ economic policies that were more oriented to structural changes and would reform in the labor market.

In the European Union, Blázquez-Fernández et al. (2018) used the Hodrick-Prescott (HP) filter and two-way ANOVA revealed an inverse relationship between unemployment and the output hold for the whole sample and subsamples. It can be understood that these countries showed smaller output loss associated with higher unemployment. Thus, the policymakers should design various ways to increase employment opportunities for diverse groups, such as on specific age cohorts, for those who were working in particular economic activities or those who were living in specific countries or macro-regions. In the four PIGS countries, Bod'a and Považanová (2015) who used the Structural Vector Autoregression stated the output gap instantaneously influenced both the male and female unemployment gaps, and vice versa. It revealed that it was established and admitted that gender was such a factor which resulted in the respective segments of the labor market to respond slightly differently to changes in the real output. In Greece, Christopoulos (2004) used Panel Data revealed the Okun's law could be confirmed for six out of the thirteen regions. The sizable structural component of the total unemployment in Greece as well as the fact that the Greek labor market was still regulated by restricting the adjustment of firms to the desired level. In the Netherlands, de la Fonteijne (2017) used Vector Autoregression and revealed that Okun's Law was not a suitable tool to estimate unemployment from the gross domestic product growth. It can be understood that the slope of the curve depended strongly on the evolution of the frequency distribution of the gross domestic product.

In the Mediterranean countries, Dimian et al. (2018) used the Panel Data revealed that agriculture was the less-sensitive sector of activity to the output fluctuations in terms of unemployment and could be a buffer for the unemployed during the recessions. The industry was highly responsive to economic developments and bad specialization could worsen the unemployment situation. In addition, educational mismatches had a significant impact on the unemployment that employed a low educated workforce. In the twenty OECD countries, Dixon et al. (2016) used Sensitivity Analysis revealed the share of temporary workers played a crucial role in explaining changes in the Okun coefficient over time. The Okun coefficient was not only different for young, prime-age and older workers, but it also decreased with age. Thus, an increase in economic growth would not only have the desired outcome of reducing the overall unemployment rate. In the four Mediterranean countries of European Union, Dritsaki and Dritsakis (2014) used Hodrick and Prescott's filter revealed the cost per unit on unemployment rate from the decrease of real gross do- 
mestic product was higher in Italy and lower in Greece. It means that the unemployment cost from the viewpoint of the loss of the real gross domestic product was larger in Italy. In the thirteen European Union countries, Economou and Psarianos (2016) used panel data and Mundlak decomposition provided evidence the Okun's law was robust to alternative specifications. It means that the effect of the output changes to unemployment rates was weaker for countries with increased labor market protection expenditures. Also, it was more persistent for countries with low labor market protection.

In the eight European Union countries, Gabrisch and Buscher (2006) used panel regressions with instrument variables that proved the transition of labor markets could be considered completed since the unemployment responded to the output changes. The labor market rigidities did not play an important role in explaining high unemployment rates. However, the gross domestic product growth was dominated by productivity progress and the employment-relevant component of aggregate demand was too low to reduce the high level of unemployment substantially. In the twenty-one, OECD countries and thirty-two Non-OECD countries, Huang and Yeh (2013) used Cross-Country Panel Data showed the unemployment output linkages were found to be negative and highly significant both in the short and longrun. Moreover, these results also proved a similar trade-off existed in the long-run. In the Eurozone Monetary Union countries, Hutengs and Stadtmann (2013) used a Linear Regression (OLS) model revealed the size of the Okun's coefficients differed quite substantially across countries. Thus, the huge gaps between unemployment rates across the EMU countries might rise social or political tension. In Nigeria, Jibir et al. (2015) used the Ordinary Least Squares and Granger causality proved there was a negative relationship between unemployment and economic growth. So, the government needs to introduce programs and policies that would create job opportunities for the teeming unemployed youths.

In the OECD countries, Kargi (2016) used the Engle-Granger Cointegration test to prove the Okun's Law existed in the twenty-three countries. It means that an increase in unemployment caused a decrease in the gross domestic product. In addition, the thirty-four OECD countries showed that a reversed relation between unemployment and growth was valid and they were cointegrate in the long-run. In Algeria, Kori Yahia (2018) used the Autoregressive Distributed Lag linear model and a Bayesian Normal Linear Regression model proved there was a negative correlation between changes in unemployment and economic growth. The results indicated that there was an Okun coefficient of -0.2 and suggested several rigidities of the labor market in Algeria. In Spain, Melguizo (2016) used Vector Autoregression and Panel VAR proved Spain's provinces showed large differences in their unemployment sensitivity to economic variations. Therefore, the provinces with less diversified industries need to develop the services sector. Also, the higher rates of labor participation were suffered from higher variations in the unemployment rates. In the G7 countries, Moosa (1997) used OLS, rolling OLS and SUR proved the employment was more responsive to the economic growth in the United States and Canada than in Europe and Japan. Furthermore, the employment was more responsive to the economic growth in the United States and Canada because of the lack of job security provisions and restrictions on layoffs.

In Malaysia, Noor et al. (2007) used Granger causality showed there was a two-way causality between the unemployment rate and output growth in Malaysia. The existence of these relationships would not solve unemployment problems. Policymakers must be creative in creating new jobs to ensure that these jobs matched with the job seeker's 
talents and skills. In the British area, Palombi, Perman, and Tavéra (2017) used the Spatial Panel approach provided evidence the regression coefficient was lower than the previously shown by cross-country evidence. Also, it was largely attributable to the spatial mechanisms which were at work in a small distance. Moreover, the interregional linkages and spillover effects from the labor mobility had important implications for the presence of Okun's law. In the G7 countries, Pierdzioch et al. (2011) used Panel Data showed there was a significant negative relationship between the expected change in the unemployment rate and the expected growth rate of the real output. Moreover, the Okun coefficient showed some variations over the year. Also, the estimated coefficients were significant and largely comparable in size to those found in studies based on the realized data. In Romania, Ruxandra (2015) used the there was a reverse relation between the gross domestic product and unemployment rates. However, fiscal and monetary policies were not sufficient to reduce unemployment. So, the government needs to promoting mobility to areas where there were vacancies.

In the thirteen developed countries, Rahman and Mustafa (2017) used Bivariate ErrorCorrection Model revealed the Okun's Law was quite valid only for the USA and South Korea. A more flexible labor market would lead to a large output gain and also the employment gain would record a lower unemployment rate. The USA and South Korea were likely to succeed in mitigating the unemployment rate by enhancing the real gross domestic product growth through monetary and expansionary fiscal policy. In the United States, Silvapulle et al. (2004) used the Asymmetric Dynamic Model provided evidence of the short-run effects of positive cyclical output on cyclical unemployment that were quantitatively different from those of negative ones. Overall, the cyclical unemployment was more sensitive to negative than to positive cyclical output. In the Eastern European Countries, Soylu et al. (2018) used Panel Data analysis revealed an increase in growth could be seen by setting unemployment-reducing measures. In addition, there was a co-integration between unemployment and growth. Thus, the governments need to consider the globalization situation, the information society requirements, and technological developments.

In the Europen countries, Tatoglu (2011) used Panel Error Correction Model showed the Okun's law exists in the European countries. Also, the significance of the relationship between the economic growth rate and the unemployment rate varied between countries. In addition, the long-run coefficients obtained from this study were lower compared to the Okun coefficient. In the European countries, Zanin and Marra (2012) used Penalized Regression Spline, Rolling Regression, and Time-Varying coefficient model found the inverse relationship in some European countries was spatially heterogeneous and time-varying. In addition, this finding confirmed that the number of coefficients increased over time, especially for Spain, France, Portugal, Ireland, and Italy. Furthermore, the coefficients for Finland and the Netherlands exhibited a change of direction during the last years. Therefore, these results had been analyzed in light of the rate of output growth needed for a stable unemployment rate proposed. In the OECD countries, Zanin (2014) used traditional Ordinary Least Squares provided evidence the estimated Okun coefficients were not always statistically significant for each subgroup of the population. These results also highlighted a general common pattern of higher Okun coefficients for the youngest cohorts. This suggested that the young population (e.g., the young male) tended to be most exposed to the business cycle in both developed and emerging OECD countries. 
In Italy, Zanin (2016) used Binary Generalized Extreme Value Additive Model found the young population was less sensitive to business cycles. As the workforce ages, this gap in sensitivity tended to shrink. In addition, there were no significant differences by gender in the number of Okun's coefficient among the youngest population.

In Indonesia, Yaumidin (2009) used the difference model and the gap model found the difference model of the Okun's Law could not be used on the Indonesian economy. Moreover, Astuti (2016) used correlation analysis showed there was no match between the Okun's law and Phillip's Curve. In order words, the economic growth and unemployment in Indonesia had a negative but not significant. However, Darman (2013) used the difference version and Ordinary Least Square models showed the Okun's coefficient was different in each country. In Indonesia, Okun's coefficient was negative. It indicates there was a relationship between economic growth and the unemployment rate. However, the significance level of Okun's coefficient was quite small. Overall, previous studies still show various results of the relationship between unemployment and output. In addition, previous studies also use many kinds of econometric modeling. Thus, it can be indicated that there is an uncertain relationship between the rate of unemployment and output in various countries. For example, the economic growth had a negative and significant effect on the unemployment rate (Abdul-Khaliq et al., 2014; Alamro \& Al-dala'ien, 2016; Bande \& Martın-RoMan, 2017; Blázquez-Fernández et al., 2018; Darman, 2013; Dritsaki \& Dritsakis, 2014; Jibir et al., 2015; Kargi, 2016; Kori Yahia, 2018; Noor et al., 2007; Pierdzioch et al., 2011; Ruxandra, 2015; Soylu et al., 2018; Tatoglu, 2011; Zanin \& Marra, 2012), the Okun's coefficient was not significant (Apergis \& Rezitis, 2003; Arewa \& Nwakanma, 2012; Astuti, 2016; Yaumidin, 2009), there were positive coefficients in the regression and it implied that the Okun's legal interpretation did not apply (Bankole \& Fatai, 2013), there was no causality between economic growth and unemployment rate (Adeyeye et al., 2017), there was a two-way causality between unemployment and output growth (Bod'a \& Považanová, 2015; Noor et al., 2007), and the Okun's coefficient was different for each country (Azorín \& de la Vega, 2017; Bande \& Martın-RoMan, 2017; Dixon et al., 2016; Hutengs \& Stadtmann, 2013; Moosa, 1997; Rahman \& Mustafa, 2017; Silvapulle et al., 2004). Based on these findings, the following hypotheses was suggested:

H0: The open unemployment has no significant influence on GDP.

Ha: The open unemployment has a significant influence on GDP.

\section{MATERIAL AND METHODS}

The secondary data obtained from Indonesia's Central Bureau of Statistics publications. Also, we use time-series data extracted from the open unemployment rate and gross domestic product in 1987 to 2017 . The open unemployment rate was measured by the percentage of unemployment in the total workforce. While the gross domestic product was measured by the total production of goods and services assessed at constant prices (Central Bureau of Statistics, 2019b).

The time-series data must find out the components of existing elements such as trend, seasonal, and cycle. Therefore, the stationarity test is needed to be done. So, we develop the stationary model which can be seen in Equation 2 (Rosadi, 2012). 


$$
\Delta Y_{t}=\beta_{1}+\beta_{2 t}+\delta \mathrm{Y}_{\mathrm{t}-1}+u_{t}
$$

The second equation reveals that $Y$ is an observed variable, $\beta$ is an intercept, $\delta$ is trend component, $\Delta$ is the first difference, $t_{-1}$ is first lag, $t$ is time and $\mathrm{u}$ is residual. After the stationarity assumptions are met, the lag length test was needed to be done. The optimal lag selection was done by selecting the AIC value (Ivanov \& Kilian, 2005). Moreover, the optimal lag can be used to run the Granger causality test. This model can be seen in Equation 3 and 4 below.

$$
\begin{aligned}
& Y_{t}=\alpha_{1}+\sum_{i=1}^{m} \beta_{i} Y_{t-i}+\sum_{j=1}^{n} \gamma_{j} X_{t-j}+\mu_{t} \\
& X_{t}=\alpha_{2}+\sum_{i=1}^{p} \phi_{i} X_{t-i}+\sum_{j=1}^{q} \Psi_{j} Y_{t-j}+\eta_{t}
\end{aligned}
$$

Equation 3 and 4 reveals that $X$ is the open unemployment rate, $Y$ is the gross domestic product, $\mu$ t and vt are error terms assumed to contain no serial correlation. Besides the Granger causality, the VAR analysis was also used particularly in VAR $(p)$ with $k$-endogenous variable (Lütkepohl, 2005). In fact, the Vector Autoregression is based on data and not theories. Thus, it can be understood that it's better to use Structural Vector Autoregression. Absolutely indeed that a Structural Vector Autoregression is based on theories. That's why the theories can be considered in this model. Therefore, we begin to develop a reduced-form of Vector Autoregression (e.g., we assume that $A$ is invertible). Therefore, it can be seen in Equation 5 below.

$$
y_{t}=\mathrm{A}_{1} y_{t-1}+\cdots+\mathrm{A}_{P} y_{t-p}+\mathrm{C} x_{t}+\epsilon_{t}
$$

Moreover, the simplified form of the error structure can be explained in Equation 6,7 , and 8 below.

$$
\begin{gathered}
\epsilon_{t}=\mathrm{A}^{-1} \mathrm{Bu}_{t}=\mathrm{Su}_{t} \\
E\left(\epsilon_{t} \in_{t}^{-1}\right)=\sum \in_{t}=A^{-1} B B^{\prime} A^{-1 \prime}=S S^{\prime} \\
S=A^{-1} B
\end{gathered}
$$

Based on Equation 6, 7, and 8 we derivative the short-run $A-B$ model as can be seen in Equation 9, 10, and 11 below.

$$
\begin{gathered}
\epsilon_{t}=\mathrm{A}^{-1} B u_{t} \\
\mathrm{~A}_{\in t}=B u_{t} \\
\sum_{\epsilon}=A^{-1} B B^{\prime} A^{-1 \prime}
\end{gathered}
$$

Amisano and Giannini (1997) stated that the restrictions on $A$ and $B$ take the structure of contemporaneous feedback of variables and the correlation structure of the errors in Structural Vector Autoregression. Furthermore, Blanchard and Quah (1989) stated that the Keynesian model consists of aggregate supply (AS), aggregate demand (AD), and monetary rule equation. We focus on the AS characterizes particularly the relationship between unemployment and output (the Okun's law). The series model will be collected in the $2 \times 1$ vector. It can be seen in Equation 12 below.

where:

$$
y_{t}=\left[y_{1 t}, y_{2 t}\right]^{\prime}=\left[y_{t}, u_{t}\right]^{\prime}
$$

$y_{t}-\mathrm{GDP}$

$u_{t}$ - Open Unemployment. 
While the structural disturbances collected in the vector can be seen in Equation 13 below.

where:

$$
e_{t}=\left[e_{2 t}\right]^{\prime}
$$

$$
e_{2 t} \text { - shock on aggregate supply. }
$$

Amisano and Giannini (1997) also stated that the relationships between $y_{t}$ and structural shocks contained in $\mathrm{e}_{\mathrm{t}}$ are determined by the $A$ and $B$ matrices. It can be seen in Equation 14 below.

$$
u_{t}=-a_{21} y_{t}+b_{22} e_{22}
$$

Thus, we can develop the short-term restriction in a Structural Vector Autoregression as can be seen in Equations below.

$$
\mathrm{A}_{\in t}=B u_{t}
$$

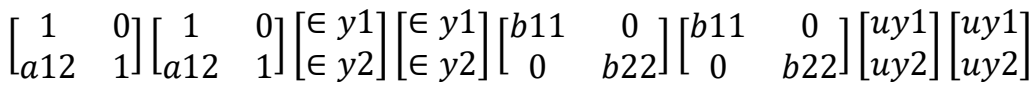

$$
\begin{aligned}
& \epsilon_{\mathrm{y} 1}=b_{11} u_{y 1} \\
& \epsilon_{\mathrm{y} 2}=-a_{21} \epsilon_{y 1}+b_{22} u_{y 2}
\end{aligned}
$$

\begin{tabular}{|c|c|c|c|}
\hline Variable & Degree of integration & p-value & Conclusion \\
\hline GDP* & $I(0)$ & 0.9990 & The series does not stationary \\
\hline $\mathrm{D}(\mathrm{GDP})^{* *}$ & $\mathrm{I}(1)$ & $0.0358 * * * * *$ & The series does stationary \\
\hline Open*** & $I(0)$ & 0.9775 & The series does not stationary \\
\hline $\mathrm{D}(\text { Open) })^{* * * *}$ & $I(1)$ & $0.0000 * * * * *$ & The series does stationary \\
\hline
\end{tabular}

So, it can be understood that Equations and Matrices show the open unemployment rate is simultaneously related to GDP and instantaneously affected by supply disturbances.

\section{FINDINGS}

The results of the time series data's stationarity test are presented in Table 1 below.

Table 1. Stationarity test

Note: $\left({ }^{*}\right)$ GDP implies the gross domestic product at constant prices.

$\left({ }^{* *}\right) \mathrm{D}(\mathrm{GDP})$ implies the gross domestic product (constant prices) at the first difference.

$(* * *)$ Open implies Indonesia's open unemployment rate.

$(* * * *) \mathrm{D}$ (Open) implies Indonesia's open unemployment rate at the first difference.

$(* * * *)$ Indicate reject the null hypothesis at the significance level of $1 \%, 5 \%$, and $10 \%$.

Source: own study.

Table 1 indicates that the gross domestic product is stationary at the first difference or I(1). This can be seen from the $p$-value of 0.0358 which is smaller than the significance level of $1 \%, 5 \%$, and $10 \%$. While the open unemployment rate is stationary at the first difference or I(1). This can be seen from the p-value of 0.0000 which is smaller than the significance level of $1 \%, 5 \%$, and $10 \%$. Also, the results of the lag length test can be seen in Table 2 below. 
Table 2. Lag length test

\begin{tabular}{|c|c|c|c|c|c|c|}
\hline Lag & LogL & LR & FPE & AIC & SC & HQ \\
\hline 0 & -444.7281 & NA & $1.14 \mathrm{e}+13$ & 35.73825 & 35.83576 & 35.76530 \\
\hline 1 & -437.4244 & 12.85461 & $8.75 \mathrm{e}+12$ & 35.47395 & 35.76648 & 35.55509 \\
\hline 2 & -428.1669 & 14.81202 & $5.80 \mathrm{e}+12$ & 35.05335 & 35.54090 & 35.18857 \\
\hline 3 & -421.2028 & $10.02827^{*}$ & $4.67 \mathrm{e}+12^{*}$ & $34.81622^{*}$ & $35.49879 *$ & $35.00554^{*}$ \\
\hline 4 & -418.8236 & 3.045373 & $5.51 \mathrm{e}+12$ & 34.94589 & 35.82348 & 35.18929 \\
\hline 5 & -418.2222 & 0.673521 & $7.69 \mathrm{e}+12$ & 35.21778 & 36.29039 & 35.51527 \\
\hline
\end{tabular}

Note: $\left(^{*}\right)$ Indicate the optimal lag.

Source: own study.

Table 2 reveals that lag 3 is the optimal lag that can explain the effect of a variable on its past variables and other endogenous variables. This is supported by the Akaike Information Criterion value of 34.81622 which is smaller than AIC value in the other lags. Based on the lag length test, the results of the Granger causality test are displayed in Table 3 below.

Table 3. Granger causality test

\begin{tabular}{|c|c|c|c|}
\hline \multicolumn{4}{|l|}{ Pairwise Granger Causality Tests } \\
\hline \multicolumn{4}{|l|}{ Sample: 19872017} \\
\hline \multicolumn{4}{|l|}{ Lags: 3} \\
\hline Null Hypothesis: & Obs. & F-Statistic & Prob. \\
\hline D(GDP) does not Granger Cause D(Open) & 27 & 0.80642 & 0.5051 \\
\hline D(Open) does not Granger Cause D(GDP) & & 13.0248 & $6 . \mathrm{E}-05^{*}$ \\
\hline
\end{tabular}

Note: $\left({ }^{*}\right)$ Do not accept the Null Hypothesis.

Source: own study.

The null hypothesis proposing that $\mathrm{D}$ (Open) does not Granger causes $\mathrm{D}(\mathrm{GDP})$ is not accepted. It means that open unemployment exhibited the Granger cause on gross domestic product. The results suggest that $\mathrm{D}$ (Open) does Granger cause $\mathrm{D}(\mathrm{GDP})$, but not vice versa. The decision to do not accepted the null hypothesis is based on the probability value of $6 . \mathrm{E}-05$ that is lower than the level significance of $5 \%$. After running the Granger causality test, this study continues to examine the Vector Autoregression test. The results of the VAR test are displayed in Table 4.

The dependent variable of the open unemployment rate is significantly affected by $D($ Open)(-1). Furthermore, the dependent variable of gross domestic product is significantly affected by $\mathrm{D}$ (Open)(-1), D(Open)(-2), D(Open)(-1), and D(GDP)(-1).

The estimates of the Vector Autoregression are also supported by the results of the white noise residual test illustrated in Table 5.

There is no correlation between residuals (the white noise residual was fulfilled). This can be seen from the $p$-value which is bigger than the significance level of $1 \%, 5 \%$, and $10 \%$. The estimates of the white noise residual are also supported by the results of the VAR stability test illustrated in Figure 1.

Figure 1 reveals there is no root lying outside the unit circle. This means that Vector Autoregression helps the stability condition as can be seen from the modulus, ranging with an average value of less than one. The estimates of Vector Autoregression stability are also supported by the Cointegration test that can be seen in Table 6 . 
Table 4. VAR model of D(Open) and D(GDP)

\begin{tabular}{|l|c|c|c|c|}
\hline \multirow{2}{*}{ Variables } & \multicolumn{2}{c|}{ D(Open) } & \multicolumn{2}{c|}{ D(GDP) } \\
\cline { 2 - 5 } & Coefficients & t-stat & Coefficients & t-stat \\
\hline $\mathrm{D}($ Open)(-1) & -0.507064 & -2.30130 & -451864.1 & -2.48228 \\
\hline $\mathrm{D}$ (Open)(-2) & -0.007229 & -0.02513 & -427920.9 & -1.80076 \\
\hline $\mathrm{D}($ Open)(-3) & 0.018076 & 0.05858 & 843913.8 & 3.31035 \\
\hline $\mathrm{D}($ GDP)(-1) & $-1.79 \mathrm{E}-07$ & -0.78135 & 0.796596 & 4.20758 \\
\hline $\mathrm{D}($ GDP)(-2) & $4.85 \mathrm{E}-08$ & 0.27173 & -0.235330 & -1.59463 \\
\hline $\mathrm{D}($ GDP)(-3) & $-2.31 \mathrm{E}-07$ & -1.38006 & 0.231356 & 1.67307 \\
\hline $\mathrm{C}$ & 1.029478 & 1.32807 & 649192.3 & 1.01370 \\
\hline $\mathrm{R}^{2}$ & 0.338941 & - & 0.748524 & - \\
\hline F-statistic & 1.709080 & - & 9.921753 & - \\
\hline Log-likelihood & -43.45258 & - & -411.3154 & - \\
\hline AIC & 3.737228 & - & 30.98632 & - \\
\hline Swarz SC & 4.073186 & - & 31.32228 & - \\
\hline
\end{tabular}

Source: own study.

Table 5. White noise residual test

\begin{tabular}{|c|c|c|}
\hline Lags & Q-Stat & Prob. \\
\hline 1 & 1.286594 & NA* \\
\hline 2 & 1.943286 & NA* $^{*}$ \\
\hline 3 & 2.872925 & NA* $^{*}$ \\
\hline 4 & 3.835771 & 0.4287 \\
\hline 5 & 6.774449 & 0.5612 \\
\hline 6 & 8.080915 & 0.7788 \\
\hline 7 & 10.55343 & 0.8362 \\
\hline 8 & 12.36713 & 0.9029 \\
\hline 9 & 13.16176 & 0.9634 \\
\hline 10 & 17.74461 & 0.9324 \\
\hline
\end{tabular}

Source own study.

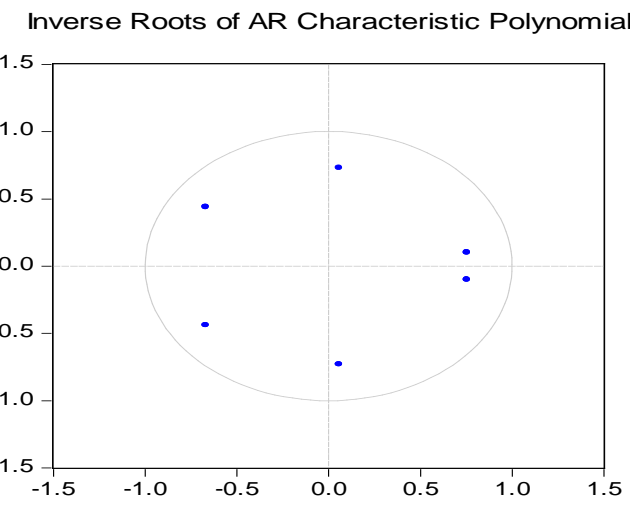

Figure 1. The VAR stability

Source: own elaboration. 
Table 6. Unrestricted cointegration rank test (Trace)

\begin{tabular}{|c|c|c|c|c|}
\hline $\begin{array}{c}\text { Hypothesized } \\
\text { No. of CE(s) }\end{array}$ & Eigenvalue & $\begin{array}{c}\text { Trace } \\
\text { Statistic }\end{array}$ & $\begin{array}{c}\mathbf{0 . 0 5} \\
\text { Critical Value }\end{array}$ & Prob.** \\
\hline None & 0.274224 & 9.551386 & 15.49471 & 0.3168 \\
\hline At most 1 & 0.045766 & 1.218016 & 3.841466 & 0.2697 \\
\hline
\end{tabular}

Note: $\left({ }^{*}\right)$ denotes rejection of the hypothesis at the significance level of $5 \%$.

$(* *)$ MacKinnon-Haug-Michelis p-values.

Source: own study.

The Trace test shows no cointegration at the significance level of $5 \%$. It means that there is no cointegration or long-term relationship between the open unemployment rate and gross domestic product. That's why we use Structural Vector Autoregression with short-term restrictions. The short-term restriction in the SVAR modeling using D(Open) and $\mathrm{D}(\mathrm{GDP})$ can be seen in the Matrices and Equations below:

$$
\begin{gathered}
A=\left[\begin{array}{cc}
1 & 0 \\
271127.8 & 1
\end{array}\right] \\
B=\left[\begin{array}{cc}
1.405606 & 0 \\
0 & 1096946 .
\end{array}\right] \\
\epsilon_{\mathrm{y} 1}=1.405606 u_{y 1} \\
\epsilon_{\mathrm{y} 2}=-271127.8 \epsilon_{y 1}+1096946 . u_{y 2}
\end{gathered}
$$

The Matrices and Equations show that $e_{y 1}$ is the residual of $\mathrm{D}(O p e n)$, while $e_{y 2}$ is the residual of $D(G D P)$. Through the formation of restrictions noted on Structural Vector Autoregression, the Structural Impulse Response Functions (SIRFs) and Structural Variance Decomposition (SVD) can be developed.

From the first year to the eighth year, the response of $D$ (Open) to shock one and two was still very volatile. While from the ninth year to the following year, the $D$ (Open) stabilized again. It means that $\mathrm{D}$ (Open) was no longer volatile like the previous period. In order words, since the ninth year, D(Open) had reached an equilibrium. Moreover, from the first to the ninth year, the response of $D(G D P)$ to shock one and two was still very volatile. While from the tenth year to the following year, the $D(G D P)$ stabilized again. It means that $\mathrm{D}(\mathrm{GDP})$ was no longer volatile like the previous period. In order words, since the tenth year, D(GDP) had reached an equilibrium. The SIRFs results were also supported by the SVD as can be seen in Table 7.

Table 7 indicates from the first year, the SVD of $D$ (Open) was strongly affected by shock one was $100 \%$. While shock 2 did not have a significant effect. In this case, when we start from the first to the tenth year, the proportion of shock one to $D(O p e n)$ was $93.20 \%$. While from the first to the tenth year, shock two had only contributed $6.79 \%$ to $\mathrm{D}$ (Open). Therefore, it was concluded magnitude of shock one had a greater effect on $\mathrm{D}$ (Open). Also, the SVD of $\mathrm{D}(\mathrm{GDP})$ can be explained in Table 8.

Table 8 reveals from the first year, SVD of D(GDP) was strongly affected by shock two was $89.22 \%$. While shock one did not have a significant effect. Starting from first to the tenth year, the proportion of shock two to D(GDP) was $57.24 \%$. However, from first to the tenth year, shock one only contributed $42.75 \%$ to $D(G D P)$. Therefore, it can be concluded the magnitude of shock two had a greater influence on $D(G D P)$. 
Response to Structural One S.D. Innovations \pm 2 S.E.

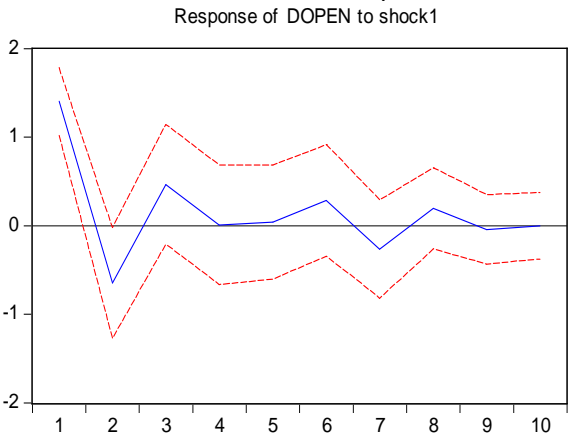

Response of DOPEN to shock2

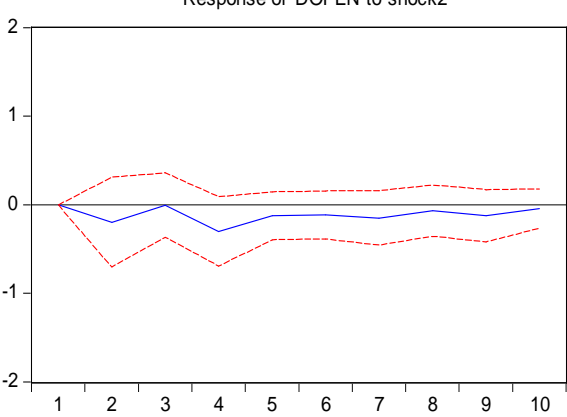

Response of DGDP to shock1
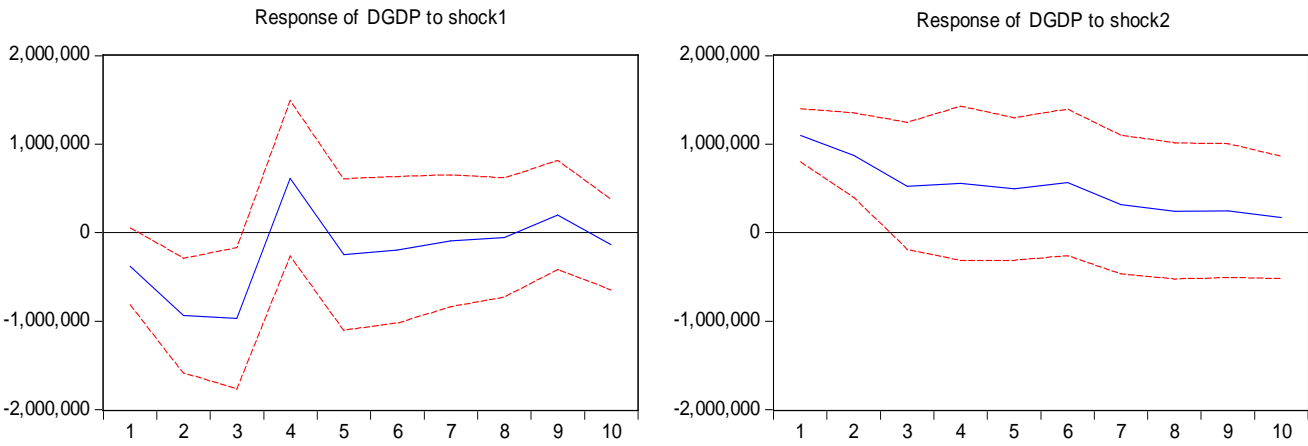

Figure 2. SIRFs of $D($ Open) and $D(G D P)$ to shock

Source: own elaboration.

Table 7. SVD of D(Open)

\begin{tabular}{|c|c|c|c|}
\hline Period & S.E. $^{*}$ & Shock1 & Shock2 \\
\hline 1 & 1.405606 & 100.0000 & 0.000000 \\
\hline 2 & 1.558743 & 98.41222 & 1.587784 \\
\hline 3 & 1.626978 & 98.54211 & 1.457891 \\
\hline 4 & 1.654801 & 95.25964 & 4.740357 \\
\hline 5 & 1.660061 & 94.71583 & 5.284173 \\
\hline 6 & 1.688556 & 94.41344 & 5.586562 \\
\hline 7 & 1.715651 & 93.81789 & 6.182109 \\
\hline 8 & 1.728264 & 93.75531 & 6.244689 \\
\hline 9 & 1.733358 & 93.26494 & 6.735061 \\
\hline 10 & 1.733907 & 93.20594 & 6.794058 \\
\hline
\end{tabular}

Note: $\left({ }^{*}\right)$ Indicate the standard error

Source: own study.

Finally, the results of SIRFs and SVD reveal that D(Open) shock has a greater influence by the shock two, rather than the shock one. On the other hand, the shock of D(GDP) has a greater influence by shock two rather than the shock one. 
Table 8. SVD of D(GDP)

\begin{tabular}{|c|c|c|c|}
\hline Period & S.E.* & Shock1 & Shock2 \\
\hline 1 & 1161260. & 10.77001 & 89.22999 \\
\hline 2 & 1730114. & 34.29132 & 65.70868 \\
\hline 3 & 2051445. & 46.67229 & 53.32771 \\
\hline 4 & 2211346. & 47.84297 & 52.15703 \\
\hline 5 & 2278907. & 46.24159 & 53.75841 \\
\hline 6 & 2356256. & 43.94280 & 56.05720 \\
\hline 7 & 2379070. & 43.25918 & 56.74082 \\
\hline 8 & 2392129. & 42.84185 & 57.15815 \\
\hline 9 & 2412962. & 42.77685 & 57.22315 \\
\hline 10 & 2422998. & 42.75183 & 57.24817 \\
\hline
\end{tabular}

Note: $\left({ }^{*}\right)$ Indicate the standard error

Source: own study.

\section{DISCUSSION}

This result is supported by Abdul-Khaliq et al. (2014); Alamro and Al-dala'ien (2016); Bande and Martın-RoMan (2017); Blázquez-Fernández et al. (2018); Dritsaki \& Dritsakis (2014); Jibir et al. (2015); Kargi (2016); Kori Yahia (2018); Noor et al. (2007); Pierdzioch et al. (2011); Ruxandra, (2015); Soylu et al. (2018); Tatoglu (2011); Zanin and Marra (2012) who found a negative relationship between open unemployment rate and gross domestic product. The negative direction indicates a decrease in $D(O p e n)$ which has implications for increasing $\mathrm{D}(\mathrm{GDP})$. This condition reveals the number of workers involved in the production process was getting bigger (Alamro \& Al-dala'ien, 2016). This is also supported by the fact there was unemployment based on the education groups which affected the GDP. It can be seen in Table 9 below.

Table 9. The impact of labor forces by education level on eeal GDP

\begin{tabular}{|c|c|c|c|c|}
\hline Variable & Coefficient & Std. Error & t-Statistic & Prob. \\
\hline C & 25190310 & 3594548. & 7.007921 & 0.0000 \\
\hline Non-School & -39.73537 & 24.95382 & -1.592356 & 0.1256 \\
\hline Not Graduate & 35.36817 & 16.07368 & 2.200378 & 0.0386 \\
\hline Elementary & 6.009163 & 6.007584 & 1.000263 & 0.3281 \\
\hline Junior & -2.091703 & 7.951573 & -0.263055 & 0.7950 \\
\hline Senior & -4.716806 & 6.872989 & -0.686282 & 0.4997 \\
\hline Vocational & 16.37103 & 7.734796 & 2.116543 & 0.0458 \\
\hline Diploma & -204.0429 & 27.44132 & -7.435605 & 0.0000 \\
\hline University & 142.0985 & 22.61086 & 6.284524 & 0.0000 \\
\hline R-squared & 0.972781 & & & \\
\hline Adjusted R-squared & 0.962883 & & & \\
\hline
\end{tabular}

Source: own study.

The increase in unemployment based on people who did not graduate from elementary school which implied an increase in the GDP. It means the increase in the GDP was not caused by the increase in the workforce from these groups. When they left the labor 
market, they were replaced by other education groups (Dimian et al., 2018; Zanin, 2016). Thus, it can be understood an increase in the GDP did not require a workforce from nonschool groups. In line with this group, the increase in unemployment based on the vocational-education level group had implications for the increase in GDP. It means the increase in GDP was not caused by the increase of labor from the vocational-education level groups. Basically, their skills were not in accordance with the needs of the labor market. The labor needs that occurred due to an increase in the GDP could not be met by the vocational-education level group. This indicates a miss-match skill from this group (Alamro \& Al-dala'ien, 2016; Dimian et al., 2018). Thus, it can be understood the group of workers originating from the vocational-education level group was not yet in accordance with the needs of the labor market. Moreover, the increase in unemployment based on the university group also had implications for the increase in GDP. It means the increase in GDP was not caused by the increase in the workforce from the university group. When they got out of the labor market, at the same time, the open unemployment rate and GDP actually increased. Thus, it can be understood the GDP increased more in labor-saving than labor-intensive (Rahman \& Mustafa, 2017; Soylu et al., 2018). However, the decline in unemployment based on the diploma group had implications for the increase in the GDP. It indicates that the diploma group was still needed in the labor market to work as teachers or educators in Islamic educational institutions. When the diploma group was involved as labor, it made the GDP increase. Thus, it is understood diploma group services were still needed in the labor market.

Moreover, there was unemployment based on the age groups which affected the GDP. It can be seen in Table 10 below.

Table 10. The impact of labor forces based on age groups on real GDP

\begin{tabular}{|c|c|c|c|c|}
\hline Variable & Coefficient & Std. Error & t-Statistic & Prob. \\
\hline C & 35829665 & 7715317. & 4.643965 & 0.0002 \\
\hline $15-19$ & 2.902234 & 13.02387 & 0.222840 & 0.8259 \\
\hline $20-24$ & 24.60280 & 14.17831 & 1.735243 & 0.0981 \\
\hline $25-29$ & -111.2787 & 47.04485 & -2.365374 & 0.0282 \\
\hline $30-34$ & 138.7546 & 103.6864 & 1.338214 & 0.1958 \\
\hline $35-39$ & -63.09374 & 104.9782 & -0.601017 & 0.5546 \\
\hline $40-44$ & 111.6198 & 122.9880 & 0.907566 & 0.3749 \\
\hline $45-49$ & 23.92157 & 141.9794 & 0.168486 & 0.8679 \\
\hline $50-54$ & -118.4486 & 159.6167 & -0.742081 & 0.4667 \\
\hline $55-59$ & 270.2433 & 187.0104 & 1.445071 & 0.1639 \\
\hline $60+$ & -73.01866 & 26.19766 & -2.787221 & 0.0114 \\
\hline R-squared & 0.757139 & - & - & - \\
\hline Adjusted R-squared & 0.635708 & - & - & - \\
\hline
\end{tabular}

Source: own study.

The unemployment of the 25-29 age group had a negative effect on the GDP. It means the decline in the open unemployment rate had implications for the increase in GDP. The decline in the open unemployment rate indicated that the 25-29 age group was involved as labor. Moreover, this group actually belonged to the productive age category (Zanin, 2014, 2016; Zanin \& Marra, 2012). Thus, it can be understood the increase in the number of productive age group had implications for the increase in GDP. 
Moreover, the unemployment of the 60+ age group also had a negative effect on the GDP. It means the decline in the open unemployment rate had implications for the increase in GDP. This indicates that the 60+ age group was involved in the labor market. This condition shows the 60+ age group was still able to work in non-formal employment and the agricultural sector. Thus, it can be understood the involvement of the 60+ age group as labor had implications for the increase in GDP (Zanin, 2016).

The one-way relationship from the open unemployment rate to GDP implies that the GDP did not affect the open unemployment rate. It can be seen in Figure 3 below.

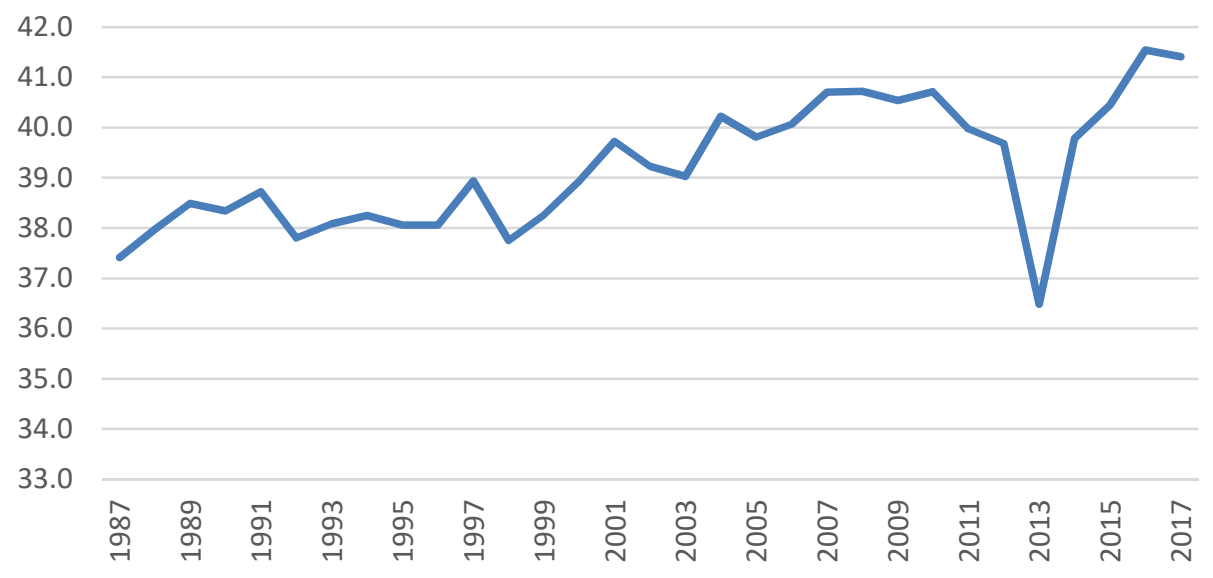

Figure 3. Working hours average

Source: Central Bureau of Statistics (2016a, 2016b, 2018, 2019c), processed.

The working hours average per week shows an increasing trend. The facts show from 37 hours in 1986, it increases to 41 hours in 2017. When the GDP increases, it should be followed by an increase in labor demand. The increase in the working hours average illustrates the fulfillment of labor needs did not originate from the additional number of workers but from the additional number of working hours (Alamro \& Al-dala'ien, 2016; Apergis \& Rezitis, 2003; Arewa \& Nwakanma, 2012; de la Fonteijne, 2017). Thus, it is understandable if the increase in GDP did not affect unemployment.

\section{CONCLUSIONS}

The labor economics policies that aim to overcome unemployment will be effective to increase the GDP in an emerging country such as Indonesia. This argument implies that declining unemployment is effective to increase the GDP. It means Okun's law notice that the more labor used in production will have implications for increasing GDP in the economy. This study is in line with Okun's law which explains the more labor used in production will have implications for increasing GDP in the economy. The negative direction showed the low unemployment rate resulted in higher GDP. An increase in GDP implied a high number of workers in the production process. It can be understood when the GDP increased, it should have been followed by an increase in demand for labor. 
Numerous facts support these findings, especially the increase in working hours average, education groups and age groups involved in the labor market. Based on Indonesia's economic structure, the majority of employment is still supported by the agricultural and the informal sector. Therefore, the government needs to encourage productive growth and absorb a lot of labor, not capital intensive growth. Our findings present evidence to support the existence of Okun's law in Indonesia. In addition, this study contributes to the literature in an emerging country by using the Structural Vector Autoregression model. However, the Indonesian geographical condition, consisting of thousands of islands, was likely caused by the implementation of labor economics policies to take a longer time. It implies the government needs to adjust to the inter-region differences.

Due to the current limitations, the Hodrick-Prescott (HP) Filter of the gap model and Structural Panel Vector Autoregression method can be used to improve the inference, not only for properties of the sample distribution but also for dynamics of individual members of the panel that lack of adequate data for a conventional time series SVAR analysis. Future research may consider long time-series and panel data to explain the impact of unemployment on the gross domestic product, and vice versa.

\section{REFERENCES}

Abdul-Khaliq, S., Soufan, T., \& Shihab, R. A. (2014). The Relationship between Unemployment and Economic Growth Rate in Arab Country. Journal of Economics and Sustainable Development, 5(9), 56-60. Retrieved on August 10, 2019 from https://www.iiste.org/Journals/index.php/JEDS/article/view/13213

Adeyeye, P. O., Odeleye, A. T., \& Aluko, O. A. (2017). Investigating Okun's Law in Nigeria through the Dynamic Model. Journal of Economics and Behavioral Studies, 9(6), 39-46. Retrieved on August 10, 2019 from https://www.researchgate.net/publication/322510549_Investigating_Okun \%27s_Law_in_Nigeria_through_the_Dynamic_Model

Alamro, H., \& Al-dala'ien, Q. (2016). Validity of Okun's Law : Empirical Evidence from Jordan. Dirasat, Administrative Sciences, 43(1), 315-324. Retrieved on August 11, 2019 from http://journals.ju.edu.jo/DirasatAdm/article/view/6788

Amisano, G., \& Giannini, C. (1997). Topics in Structural VAR Econometrics (2nd ed.). Retrieved on August 10, 2019 from https://www.springer.com/gp/book/9783642644818

Apergis, N., \& Rezitis, A. (2003). An examination of Okun's law: Evidence from regional areas in Greece. Applied Economics, 35(10), 1147-1151. https://doi.org/10.1080/0003684032000066787

Appiah, M., Li, F., Frowne, D. I., \& Donkor, D. T. (2019). Foreign investment and growth: A case of selected African economies. International Entrepreneurship Review, 5(3), 7-18. https://doi.org/10.15678/IER.2019.0503.01

Arewa, A., \& Nwakanma, P. C. (2012). Potential-Real GDP Relationship and Growth Process of Nigerian Economy: an Empiriical Re- Evaluation of Okun's Law. European Scientific Journal, 8(9), 25-33. Retrieved on August 12, 2019 from https://eujournal.org/index.php/esj/article/view/143

Astuti, P. B. (2016). Analisis Kurva Phillips dan Hukum Okun di Indonesia tahun 1986-2016. Fokus Bisnis, 15(1), 72-91. Retrieved on August 11, 2019 from http://journal.stieputrabangsa.ac.id/index.php/fokbis/article/view/72

Azorín, J. D. B., \& de la Vega, M. d-M. S. (2017). Output growth thresholds for the creation of employment and the reduction of unemployment: A spatial analysis with panel data from the Spanish provinces, 2000-2011. Regional Science and Urban Economics, 67, 42-49. https://doi.org/10.1016/j.regsciurbeco.2017.08.004 
Bande, R., \& Martın-RoMan, A. L. (2017). Regional differences in the Okun's Relationship: New Evidence for Spain (1980-2015). In Munich Personal RePEc Archive Paper (No. 79833). Retrieved on August 12, 2019 from https://mpra.ub.uni-muenchen.de/79833/

Bankole, A. S., \& Fatai, B. O. (2013). Empirical Test of Okun's Law in Nigeria. International Journal of Economic Practices and Theories, 3(3), 227-231. Retrieved on August 10, 2019 from http://www.ijept.org/index.php/ijept/article/view/Empirical_Test_of_Okun_Law_in_Nigeria/pdf

Blanchard, O. J., \& Quah, D. (1989). The Dynamic Effects of Aggregate Demand and Supply Disturbances. The American Economic Review, 79(4), 655-673. https://doi.org/10.1016/01651765(95)00680-E

Blázquez-Fernández, C., Cantarero-Prieto, D., \& Pascual-Sáez, M. (2018). Okun's Law in Selected European Countries (2005-2017): An Age and Gender Analysis. Economics \& Sociology, 11(2), 263-274. https://doi.org/10.14254/2071-789x.2018/11-2/18

Bod'a, M., \& Považanová, M. (2015). Gender Asymmetry in Okun's Law in the Four PIGS Countries. Procedia Economics and Finance, 30, 111-123. https://doi.org/10.1016/s2212-5671(15)01260-5

Central Bureau of Statistics. (2016a). Penduduk Berumur 15 Tahun Ke Atas yang Bekerja Selama Seminggu yang Lalu Menurut Golongan Umur dan Jumlah Jam Kerja Seluruhnya, 1986-1996. Retrieved on August 10, 2019 from Central Bureau of Statistics website: https://www.bps.go.id/statictable/2014/09/15/979/penduduk-berumur-15-tahun-ke-atasyang-bekerja-selama-seminggu-yang-lalu-menurut-golongan-umur-dan-jumlah-jam-kerjaseluruhnya-1986-1996.html

Central Bureau of Statistics. (2016b). Penduduk Berumur 15 Tahun Ke Atas yang Bekerja Selama Seminggu yang Lalu Menurut Golongan Umur dan Jumlah Jam Kerja Seluruhnya, 1997-2007. Retrieved on August 10, 2019 from Central Bureau of Statistics website: https://www.bps.go.id/statictable/2016/04/11/1933/penduduk-berumur-15-tahun-ke-atasyang-bekerja-selama-seminggu-yang-lalu-menurut-golongan-umur-dan-jumlah-jam-kerjaseluruhnya-1997---2007.html

Central Bureau of Statistics. (2018). Penduduk 15 Tahun Ke Atas yang Bekerja menurut Lapangan Pekerjaan Utama 1986-2017. Retrieved on August 10, 2019 from Central Bureau of Statistics website: https://www.bps.go.id/statictable/2009/04/16/970/penduduk-15-tahun-ke-atasyang-bekerja-menurut-lapangan-pekerjaan-utama-1986---2018.html

Central Bureau of Statistics. (2019a). Tingkat Pengangguran Terbuka (TPT) Menurut Provinsi, 1986 2018. Retrieved on August 10, 2019 from Central Bureau of Statistics website: https://www.bps.go.id/statictable/2014/09/15/981/tingkat-pengangguran-terbuka-tptmenurut-provinsi-1986---2018.html

Central Bureau of Statistics. (2019b). Penduduk Berumur 15 tahun ke atas menurut jenis kegiatan tahun 1986 - 2018. Retrieved on August 10, 2019 from Central Bureau of Statistics website: https://www.bps.go.id/statictable/2009/04/16/969/penduduk-berumur-15-tahun-ke-atasmenurut-jenis-kegiatan-tahun-1986---2018.html

Central Bureau of Statistics. (2019c). Penduduk Berumur 15 Tahun Ke Atas yang Bekerja Selama Seminggu yang Lalu Menurut Golongan Umur dan Jumlah Jam Kerja Seluruhnya, 2008 - 2018. Retrieved on August 10, 2019 from Central Bureau of Statistics website: https://www.bps.go.id/statictable/2016/04/11/1934/penduduk-berumur-15-tahun-ke-atasyang-bekerja-selama-seminggu-yang-lalu-menurut-golongan-umur-dan-jumlah-jam-kerjaseluruhnya-2008---2018.html

Christopoulos, D. K. (2004). The relationship between output and unemployment: Evidence from Greek regions. Papers in Regional Science, 83, 611-620. https://doi.org/10.1016/b0-08-0430767/02507-9 
Darman. (2013). Effect of Economic Growth on Unemployment Rate: Analysis of Okun's Law. The Winners, 14(1), 1-12.

de la Fonteijne, M. R. (2017). Okun's Law, Dead or Alive: A Fundamental. In Munich Personal RePEc Archive (No. 83911). Retrieved on August 10, 2019 from https://mpra.ub.unimuenchen.de/83911/

Dimian, G. C., Aceleanu, M. I., Ileanu, B. V, \& Șerban, A. C. (2018). Unemployment and Sectoral Competitiveness in Southern European Union Countries. Facts and Policy Implications. Journal of Business Economics and Management, 19(3), 474-499. https://doi.org/10.3846/jbem.2018.6581

Dixon, R., Lim, G. C., \& van Ours, J. C. (2016). Revisiting the Okun's relationship. In Discussion Paper (No. 9815). https://doi.org/10.1080/00036846.2016.1245846

Dritsaki, C., \& Dritsakis, N. (2014). Okun's Coefficient for Four Mediterranean Member Countries of EU: An Empirical Study. International Journal of Business and Management, 4(5), 18-26. https://doi.org/10.5539/ijbm.v4n5p18

Economou, A., \& Psarianos, I. N. (2016). Revisiting Okun's Law in European Union countries. Journal of Economic Studies, 43(2), 275-287. https://doi.org/10.1108/JES-05-2013-0063

Gabrisch, H., \& Buscher, H. (2006). The relationship between unemployment and outpu in post-communist countries. Post-Communist Economies, 18(3), 261-276. https://doi.org/10.1080/14631370600881804

Huang, H. C., \& Yeh, C. C. (2013). Okun's law in panels of countries and states. Applied Economics, 45(2), 191-199. https://doi.org/10.1080/00036846.2011.597725

Hutengs, O., \& Stadtmann, G. (2013). Age effects in Okun's law within the Eurozone. Applied Economics Letters, 20(9), 821-825. https://doi.org/10.1080/13504851.2012.750416

Ivanov, V., \& Kilian, L. (2005). A practitioner's guide to lag order selection for VAR impulse response analysis. Studies in Nonlinear Dynamics \& Econometrics, 9(1), 1-36. Retrieved on August 10, 2019 from http://drphilipshaw.com/Protected/A Practitioners Guide to Lag Order Selection for VAR Impulse Response Analysis.pdf

Jibir, A., Bappayaya, B., \& Babayo, H. (2015). Re-Examination of the Impact of Unemployment on Economic Growth of Nigeria: An Econometric Approach. Journal of Economics and Sustainable Development, 6(8), 116-124. Retrieved on August 15, 2019 from https://www.iiste.org/Journals/index.php/JEDS/article/view/21912

Kargi, B. (2016). Okun's Law and Long Term Co-Integration Analysis for OECD Countries (1987-2012). Emerging Markets Journal, 6(1), 39-46. https://doi.org/10.5195/emaj.2016.92

Kori Yahia, A. (2018). Estimation of Okun Coefficient for Algeria. In Munich Personal RePEc Archive (No. 83707). Retrieved on August 10, 2019 from https://mpra.ub.uni-muenchen.de/83707/

Lütkepohl, H. (2005). New Introduction to Multiple Time Series Analysis. Berlin: Springer-Verlag Berlin and Heidelberg $\mathrm{GmbH} \&$ Co. Retrieved on August 14, 2019 from http://www.afriheritage.org/TTT/2 New Introduction to Multiple Time Series Analysis.pdf

Melguizo, C. (2016). An analysis of Okun's law for the Spanish provinces. Review of Regional Research, 37(1), 59-90. https://doi.org/10.1007/s10037-016-0110-7

Mishkin, F. S. (2016). The Economics of Money, Banking, and Financial Markets (11th ed.). Retrieved on August 10, 2019 from http://noahc.me/2016 Frederic Mishkin - The Economics of Money, Banking and Financial Markets\%5B11thED\%5D\%5BGlobalED\%5D_Real.pdf

Moosa, I. A. (1997). A Cross-Country Comparison of Okun's Coefficien. Journal of Comparative Economics, 24(3), 335-356. Retrieved from https://doi.org/10.1006/jcec.1997.1433

Noor, Z. M., Nor, N. M., \& Ghani, J. A. (2007). The Relationship Between Output and Unemployment in 
Malaysia: Does Okun's Law Exist? International Journal of Economics and Management, 1(3), 337344. Retrieved on August 10, 2019 from http://psasir.upm.edu.my/id/eprint/671/1/bab02.pdf

Okun, A. M. (1962). Potential GNP: Its measurement and significance (No. 190). Retrieved on August 10, 2019 from https://milescorak.files.wordpress.com/2016/01/okun-potential-gnp-itsmeasurement-and-significance-p0190.pdf

Palombi, S., Perman, R., \& Tavéra, C. (2017). Commuting effects in Okun's Law among British areas: Evidence from spatial panel econometrics. Papers in Regional Science, 96(1), 191-209. https://doi.org/10.1111/pirs.12166

Pawęta, B. (2018). Impact of the global financial crisis on the business cycle in the Visegrad group. Entrepreneurial Business and Economics Review, 6(3), 43-58. https://doi.org/10.15678/EBER.2018.060303

Pierdzioch, C., Rülke, J.-C., \& Stadtmann, G. (2011). Do professional economists' forecasts reflect okun's law? some evidence for the G7 countries. Applied Economics, 43(11), 1365-1373. https://doi.org/10.1080/00036840802600400

Rahman, M., \& Mustafa, M. (2017). Okun's law: evidence of 13 selected developed countries. Journal of Economics and Finance, 41(2), 297-310. https://doi.org/10.1007/s12197-015-9351-5

Rosadi, D. (2012). Ekonometrika dan Analisis Runtun Waktu Terapan Dengan Eviews. Yogyakarta: ANDI.

Ruxandra, P. (2015). The Specifics Of Okun's Law In The Romanian Economy Between 2007 And 2013. Annals - Economy Series, 1(II), 50-53. Retrieved on August 10, 2019 from http://www.utgjiu.ro/revista/ec/pdf/2015-01.Volumul 2/07_Pitorac.pdf

Sasongko, G, Huruta, A. D., \& Pirzada, K. (2019). Why labor force participation rate rises? New empirical evidence from Indonesia. Entrepreneurship and Sustainability Issues, 7(1), 166-176. https://doi.org/10.9770/jesi.2019.7.1(13)

Sasongko, G, Huruta, A. D., \& Gultom, Y. N. V. (2019). Does the Phillips Curve exist in Indonesia? A Panel Granger Causality Model. Entrepreneurship and Sustainability Issues, 6(3), 1428-1443. https://doi.org/10.9770/jesi.2019.6.3(26)

Silvapulle, P., Moosa, I. A., \& Silvapulle, M. J. (2004). Asymmetry in Okun's law. Canadian Journal Of Economics, 37(2), 353-374. Retrieved on August 10, 2019 from http://www.jstor.org/stable/3696151

Soylu, Ö. B., Çakmak, I., \& Okur, F. (2018). Economic growth and unemployment issue: Panel data analysis in Eastern European Countries. Journal of International Studies, 11(1), 93-107. https://doi.org/10.14254/2071-8330.2018/11-1/7

Tatoglu, F. Y. (2011). The Long and short run effects between unemployment and economic growth in Europe. Doğuş Üniversitesi Dergisi, 12(1), 99-113. Retrieved on August 13, 2019 from https://core.ac.uk/download/pdf/47254185.pdf

Yaumidin, U. K. (2009). Output and Unemployment: Testing Okun's Law in Indonesia. Review of Indonesian Economics and Business Studies, 6(6), 43-74. Retrieved on August 10, 2019 from http://jurnalekonomi.lipi.go.id/index.php/riebs/article/view/84/39

Zanin, L. (2014). On Okun's law in OECD countries: An analysis by age cohorts. Economics Letters, 125(2), 243-248. https://doi.org/10.1016/j.econlet.2014.08.030

Zanin, L. (2016). The pyramid of Okun's coefficient for Italy. Empirica, 45(1), 12-28. https://doi.org/10.1007/s10663-016-9343-5

Zanin, L., \& Marra, G. (2012). Rolling regression versus time-varying coefficient modelling: An empirical investigation of the Okun's law in some Euro area countries. Bulletin of Economic Research, 64(1), 91-108. https://doi.org/10.1111/j.1467-8586.2010.00376.x 


\section{Authors}

The contribution share of authors is equal and amounted to $50 \%$ each of them.

\section{Cheng-Wen Lee}

Professor in the Department of International Business, College of Business, Chung Yuan Christian University (CYCU) Taiwan. Research interests: Management. environmental or technological innovation and transfer, multinational or global strategies (e.g., M \& A, strategic alliance, joint venture), and knowledge management.

Correspondence to: Prof. Cheng-Wen Lee, Ph.D., Department of International Business, Chung Yuan Christian University, 200 Chung Pei Road, Chung Li District, Taoyuan City, 32023, Taiwan, ROC, e-mail: chengwen@cycu.edu.tw

ORCID (1) http://orcid.org/0000-0002-4811-7000

\section{Andrian Dolfriandra Huruta}

Ph.D. Student in the Ph.D. Program in Business, College of Business, Chung Yuan Christian University (CYCU) Taiwan. Research interest: macroeconomic policies, international trade, and applied econometrics.

Correspondence to: Andrian Dolfriandra Huruta, Ph.D. Program in Business, Chung Yuan Christian University, 200 Chung Pei Road, Chung Li District, Taoyuan City, 32023, Taiwan, ROC, e-mail: g10804610@cycu.edu.tw (the Corresponding Author)

ORCID (1) http://orcid.org/0000-0001-7676-5294

\section{Acknowledgements and Financial Disclosure}

The authors would like to thank the anonymous reviewers for their valuable reviews, which have improved the quality of this paper.

\section{Copyright and License}

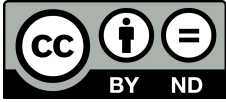

This article is published under the terms of the Creative Commons

Attribution - NoDerivs (CC BY-ND 4.0) License http://creativecommons.org/licenses/by-nd/4.0/

Published by the Centre for Strategic and International Entrepreneurship - Krakow, Poland 
